then yielded a quantity proportional to $E_{T}^{\prime}$. Since only the value of $E_{T}$ normalized to that at room tomporature was required, the proportionality constant was cancellod out. The moasuroment was carried out in the range from $77^{\circ} \mathrm{K}$ to $293^{\circ} \mathrm{K}$ and the results plotted in Fig. 1. The agreoment between tho oxpcrimental data and the theorotical calculation for $\alpha=0.135$ is nearly perfect.

This yields a total cavity loss of 43 por cent per pass in the ruby rod studied. The ond reflectivity loss contributes 11 per cent per pass. Assuming the diffraction loss and other end losses of 25 per cent, the scattering loss is 7 per cont per pass. These results are very comparable to those measured at reduced temperature on other Linde ruby laser rods grown during the same period of timo ${ }^{2}$.

The method describod here eliminates the inaccuracy and difficulty due to the non-linear property of flashtube in the conventional laser cavity loss measurements. Since measurements are made at rclatively high pumping input, there is no noed to search tediously for the threshold pumping energy. The measurement rosults obtained indicate that the cavity loss is essontially constant over the temperature-range investigated, and the assumed four-level system is an adequate description for tho pulsed ruby lnser.

I thank R. L. Aagard and J. F. Ready for their advice, and $(x . N$. Otto for making the experimental measurements.

Honeywell Research Center,

D. CheN Hopkins, Minnesota.

'Colling, R. J., and Netson, D. F., Proc. Conf. Opt. Inst., London (1001).

${ }^{3}$ Aagard, R. L., J. Opt. Soc. Amer, 53, 911 (1963).

${ }^{8}$ Masters, J. I., Nature, 199, 442 (1963).

- Nelson, D, F., and Remeika, J. P.. J. App. Phys., 35, 592 (1964).

"Aaguri, R, L., and Dufault, R. A., App. Phys. Letters, 4, 102 (1964). - Nelaon, D. F., and MeCumber, D. E., Proc. Third Intern. Symp. Quantum
Electronics, 1003 (to bo published).

'Aagard, R. L., J. App. Phys, 34, 3631 (1968).

8.McCumber, D. E., and Sturgc, M. D., J.App. Phys., 34, 1682 (1963),

\section{Three-body Ionic Recombination}

Thomson's theory ${ }^{1}$ of three-body rocombination of positive and negativo ions:

$$
A^{+}+B-+M \rightarrow A+B+M
$$

invokes tho artifico of a fictitious trapping distance such that rocombination may be supposed to oceur if oither ion collides with a noutral moloculo when within this distance from the othor. In recent years the theory has been elaborated by several invostigators ${ }^{2}$ and tho predictions regarding tho recombination coefficient have consoquently been considerably modified. However, tho basic artifice is retained though it does not form an altogether satisfactory foundation on which to build a precise theory. We here outline an entirely different approach exploiting the fact that a quasi-equilibrium is quickly established in which tho rate at which bound ionpairs are formed and destroyed is very much greater than the rate at which their number density changes ${ }^{3}$. In so far as the contribution from charge transfer is merely additive, our approach is effectively oxact in the region where the three-body rocombination coefficient $\alpha$ is directly proportional to the numbor density, $N(M)$, of noutral atoms.

Let the number donsity of ion-pairs having internal energy between $x$ and $x+\mathrm{d} x$ be $n(x) \mathrm{d} x$ in the quasiequilibrium state and bo $n_{0}(x) \mathrm{d} x$ in thermodynamic equilibrium. Write:

$$
\begin{aligned}
P(x) & =n(x) / n_{0}(x), x<0 \\
& =1, x>0
\end{aligned}
$$

Considering a gas of neutral atoms and ion-pairs of internal energy" $x$ denote tho rate coofficient describing those collisions which change the intornal energy to betweon $y$ and $y+\mathrm{d} y$ by $K(x, y) \mathrm{d} y$.
In the quasi-equilibrium state we have that:

$$
n(x) \int_{-I}^{\infty} K(x, y) \mathrm{d} y=\int_{-I}^{\infty} n(y) K(y, x) \mathrm{d} y
$$

where $-I$ is the most negative internal energy reached. With the aid of (2) and the principle of detailed balancing it may be shown that (3) is equivalent to:

$$
\rho(x) \int_{-I}^{\infty} K(x, y) \mathrm{d} y=\int_{-I}^{\infty} \mathrm{\rho}(y) K(x, y) \mathrm{d} y
$$

If $K(x, y)$ is known (and in any particular case it may be calculated) this intogral oquation for $p(x)$ may be solved to any desired accuracy. The rate recombination equals the net rate at which ion-pairs flow downwards in $x_{-}^{-}$spaco past any fixed level $-J$ so that:

$$
\alpha N\left(A^{+}\right) N\left(B^{-}\right)=N(M) \int_{y=-J}^{\infty} \int_{x=-I}^{-J}\{n(y) K(y, x)-n(x) K(x, y)\} \mathrm{d} x \mathrm{~d} y(5)
$$

where $N\left(A^{+}\right)$and $N\left(B^{-}\right)$are the number densities indicated. Hence $\alpha$ may be found.

Wo have as yet carried out detailed computations only on ions recombining in their paront gas (for which case $K$ is doterminod by resonance charge transfer). The preliminary value which we obtained for $\alpha$ in this special case does not diffor appreciably from that given by the original simple formula of Thomson (as corrected by Locb ${ }^{1}$ ) and the temperature dependence is the same. $A$ fuller account of the work will be published elsewhero.

This work was supported by the U.S. Offico of Naval Research for the Advanced Research Projects Ageney Department of Defenso under contract $N$ 62558-3634.

Departmont of Applied Mathematics,

$$
\begin{aligned}
& \text { D. R. BATES } \\
& \text { R. J. MOFETT* }
\end{aligned}
$$

Tho Queen's University of Belfast,

* Present address: South West Conter for Advaneed Studies, Dallas, Texas. ${ }^{1}$ Thomson, T. J., Phil. Mag., 47, 337 (1934), A minor error in this paper has
been pointed out by Loeb, L. B., in F'undamental Processes of Electrical Discharges in Gases, 110 (New York, John Wiley and Sons, 1939).

'Natangon, G. L, Soviet Phys.-Tech. Phys., 4, 1373 (1960). Brueckner, K. A., J. Chem. Phys., 40, 439 (1964).

${ }^{3}$ Compare with Bates, D. R., Kingston, A. E., and McWhirter, R. W. P., Froe. Roy. Soc., A, $26 \%$,' 297 (1962).

\section{GEOLOGY}

\section{Late Quaternary Terraces on Mount Carmel (Haifa, Israel)}

REMNANTS of two marine quaternary terraces, corresponding to a sen-lovel of $5 \mathrm{~m}$ and $15 \mathrm{~m}$ above sea-level respectively, have been revealed by borcholes and excavations during housing projects on the N.N.E. piedmont of Mt. Carmel in Haifa, Tsrael.

The area of approximately two square kilometros, known as the Kyriat Eliahu suburb of Haifa, is covered mainly with alluvial soils and some mountain talus. Numerous middle palacolithic artefacts ${ }^{1}$ which are obviously non in situ have been found scatterod ovor the surfaco. In several places tho bore holes and excavations encountered marine calcareous sandstone, resting on a platform cut in the mountain formations (dolomito and marly chalk of Conomanian age) (Fig. 1).

The younger (lower) terrace has been tracod on a stretch of $1.5 \mathrm{~km}$ up to the present shore (Fig. 2). A conglomorate, $0.5 \mathrm{~m}$ thick, cemented by calcareous sandstone and typical of beach environment, was found resting on a chalky bedrock at $4 \mathrm{~m}$, thus determining the level of the terrace-forming sea as approximately $5 \mathrm{~m}$ above the present sea. The calcareous sandstone is light in colour, is virtually unwentherod and is mainly of an oolitic type ${ }^{2}$. Its maximum thickness known so far is $1 \mathrm{~m}$. The calcareous sundstone is 